\title{
Exclusion of dietary sodium bicarbonate from a wheat-based diet: Effects on milk production and ruminal fermentation
}

\author{
L. Doepel ${ }^{\star 1,2}$ and A. Hayirli† \\ *Department of Agricultural, Food and Nutritional Science, University of Alberta, Edmonton, AB, Canada T6G 2P5 \\ †Department of Animal Nutrition and Nutritional Disorders, Faculty of Veterinary Medicine, Atatürk University, Erzurum 25700, Turkey
}

\begin{abstract}
Milk production, rumen fermentation, and wholetract apparent nutrient digestibility in response to feeding $20 \%$ steam-rolled wheat with or without sodium bicarbonate were evaluated in 12 Holstein cows averaging $165 \pm 16$ DIM. Cows were fed 1 of 2 isoenergetic and isonitrogenous diets containing either 0 or $0.75 \%$ sodium bicarbonate on a DM basis for $21 \mathrm{~d}$ in a crossover design. Rumen fluid samples were obtained 18 times during the last $2 \mathrm{~d}$ of each period, and fecal samples were collected on 12 occasions from d 18 to 21 of each period. Removal of sodium bicarbonate from the diet did not affect DMI $(21.0 \mathrm{~kg} / \mathrm{d})$, yields of milk $(30.8 \mathrm{~kg} / \mathrm{d})$, or milk components $(1.16,1.01$, and $1.40 \mathrm{~kg} / \mathrm{d}$ for fat, protein, and lactose, respectively). Whole-tract apparent digestibility of DM, CP, ADF, and NDF did not differ between the 2 treatments (75.3, $76.6,67.2$, and $63.6 \%$, respectively). The mean rumen $\mathrm{pH}$ was 6.24 and was not affected by excluding sodium bicarbonate from the diet. Rumen $\mathrm{NH}_{3}-\mathrm{N}(12.31 \mathrm{mg} /$ $\mathrm{dL})$ and lactic acid $(3.63 \mathrm{mM})$ concentrations were not different, whereas total volatile fatty acids concentration tended to increase when sodium bicarbonate was present in the diet (110 vs. $116 \mathrm{mM}$ ). However, average concentrations of the individual volatile fatty acids, as a proportion of total volatile fatty acids, were not affected by treatment. In conclusion, dairy cow diets can include up to $20 \%$ steam-rolled wheat without the need for added sodium bicarbonate as long as the diets are formulated to meet the fiber requirements of the cow.
\end{abstract}

Key words: lactation, rumen fermentation, sodium bicarbonate, wheat

\section{INTRODUCTION}

Energy requirements for high levels of milk production typically are met with a diet containing 50 to $60 \%$

\footnotetext{
Received May 28, 2010.

Accepted September 12, 2010.

${ }^{1}$ Corresponding author: ldoepel@ucalgary.ca

${ }^{2}$ Current address: University of Calgary Faculty of Veterinary Medicine, AB, Canada T2N 4Z6.
}

concentrates. At these levels, a reduction in ruminal $\mathrm{pH}$ might occur due to high levels of rapidly fermentable carbohydrates and depressed saliva production; this in turn depresses fiber digestion and leads to subacute ruminal acidosis and other acidosis-related metabolic disturbances (Garrett et al., 1999). Thus, buffers are often used in high-energy rations to control the acidity of the rumen and to avoid reductions in DMI and milk fat depression.

Sodium bicarbonate is one of the most commonly used dietary buffers and prevents ruminal $\mathrm{pH}$ reduction by neutralizing excess protons (Le Ruyet and Tucker, 1992); increasing water intake, ruminal fluid dilution rate, and flow of undegraded starch from the rumen; and decreasing ruminal propionate production (Russell and Chow, 1993). It may be used alone or in combination with another buffer such as sodium carbonate. Xu et al. (1994; experiment 1) tested the effect of commercial buffers (Alkaten supplying the diet with $0.65 \%$ sodium carbonate and $0.52 \%$ sodium bicarbonate, and Rumen 8 supplying the diet with $0.54 \%$ sodium carbonate and $0.40 \%$ sodium bicarbonate) supplied in a lactation diet containing $40 \%$ grass silage, $12 \%$ whole cottonseed, and $48 \%$ concentrate. Dry matter intake and milk production were not different between cows fed the control diet and those fed the diets with buffers. Rumen $\mathrm{pH}$ was not influenced by the addition of buffers. With diets containing $68 \%$ concentrate (Xu et al., 1994; experiment 2), rumen $\mathrm{pH}$ was not different, but $3.5 \%$ FCM was higher with the buffered diets. This may suggest that sodium carbonate and sodium bicarbonate in combination may be sufficient to minimize the risk for ruminal acidosis but not for milk fat depression if they are not increased proportionally with concentrate percentage. Khorasani and Kennelly (2001) fed late-lactation cows (240 DIM) diets containing either 50 or $75 \%$ concentrate with or without $1.2 \%$ sodium bicarbonate on a DM basis and found that although DMI was unaffected by buffer inclusion $4 \%$ FCM was increased. Similar to the study by Xu et al. (1994), rumen $\mathrm{pH}$ was unaffected by treatment. When cows in early lactation (100 DIM) were fed the same diets as those in late lactation, similar results were found: no 
change in DMI but an increase in 4\% FCM, likely due to the significant increase in ruminal acetate (Kennelly et al., 1999).

Barley and corn are commonly used grains for dairy cattle. Wheat, although widely grown in western Canada, is not fed to dairy cows in any substantial quantity because of cost and the belief that it is too rapidly degraded in the rumen and will result in subacute rumen acidosis. However, in our previous work (Doepel et al., 2009), we demonstrated no negative effects from feeding steam-rolled wheat at up to $20 \%$ of dietary DM on lactation and cow health when the diet was supplemented with $0.5 \%$ sodium bicarbonate. The objective of this subsequent experiment was to determine if removal of sodium bicarbonate as a buffer source from a diet with $20 \%$ wheat grain would affect production, rumen fermentation, or whole-tract nutrient digestibility.

\section{MATERIALS AND METHODS}

\section{Cows, Diets, and Management}

Twelve second-lactation Holstein cows averaging 165 \pm 16 DIM (mean $\pm \mathrm{SD}$ ) were randomly assigned to 1 of 2 treatments in a crossover design with 21 -d periods, with the first $14 \mathrm{~d}$ for treatment adaptation and the last $7 \mathrm{~d}$ for data collection. Average BW was $597 \pm 50$ $\mathrm{kg}$ (mean $\pm \mathrm{SD}$ ) at the beginning of the experiment, and $613 \pm 50 \mathrm{~kg}$ at the end of the experiment. Six of the cows were previously fitted with ruminal cannulas (10 cm i.d.; Bar Diamond Inc., Parma, ID). The 2 treatments (Table 1) were isoenergetic and isonitrogenous diets containing on a DM basis $20 \%$ steam-rolled wheat with $0.75 \%$ sodium bicarbonate (control, CTL) or without sodium bicarbonate (NSB). This amount of sodium bicarbonate was chosen to provide $175 \mathrm{~g} / \mathrm{d}$ at an estimated intake of $23 \mathrm{~kg} / \mathrm{d}$ (NRC, 2001). The diets were fed ad libitum as a TMR twice daily in equal portions at $1030 \mathrm{~h}$ and $1630 \mathrm{~h}$. Ration DM adjustment, cow management, and milking protocol were as described previously (Doepel et al., 2009). Feed intake and milk production were recorded daily throughout the experiment, with data for the last $7 \mathrm{~d}$ of each period used for analysis. Milk samples were collected on d 19 and 20 of each period during the morning and evening milkings. Cows were cared for in accordance with Canadian Council on Animal Care guidelines (CCAC, 1993), and the experimental procedures were approved by the Animal Care and Use Committee for Livestock at the University of Alberta (Edmonton, AB, Canada).

\section{Sampling and Analysis}

Ruminal fluid (approximately $150 \mathrm{~mL}$ ) was sampled 18 times over a 24 -h period beginning on d 20 following
Table 1. Ingredient and nutrient composition of the experimental diets

\begin{tabular}{|c|c|c|}
\hline \multirow[b]{2}{*}{ Item } & \multicolumn{2}{|c|}{ Treatment $^{1}$} \\
\hline & NSB & CTL \\
\hline \multicolumn{3}{|c|}{ Ingredient composition, \% DM } \\
\hline Alfalfa hay & 15.3 & 15.2 \\
\hline Barley silage & 34.7 & 34.7 \\
\hline Barley grain, steam-rolled & 10.5 & 9.8 \\
\hline Wheat grain, steam-rolled & 20.0 & 20.0 \\
\hline Corn grain, steam-rolled & 5.1 & 5.1 \\
\hline Canola meal & 2.0 & 2.0 \\
\hline Corn gluten meal & 5.6 & 5.6 \\
\hline Fish meal & 1.9 & 1.9 \\
\hline Canola oil & 1.5 & 1.5 \\
\hline Rumen bypass fat ${ }^{2}$ & 1.1 & 1.1 \\
\hline Molasses & 1.0 & 1.0 \\
\hline Sodium bicarbonate & - & 0.75 \\
\hline Limestone & 0.2 & 0.2 \\
\hline Dicalcium phosphate & 0.2 & 0.2 \\
\hline Magnesium oxide & 0.1 & 0.1 \\
\hline Mineral-vitamin premix ${ }^{3}$ & 0.7 & 0.7 \\
\hline Vitamin $\mathrm{E}^{4}$ & 0.1 & 0.1 \\
\hline \multicolumn{3}{|c|}{ Chemical composition, ${ }^{5} \%$ of DM } \\
\hline $\mathrm{DM}$ & 42.5 & 42.5 \\
\hline $\mathrm{CP}$ & 17.3 & 17.6 \\
\hline NDF & 33.2 & 33.9 \\
\hline $\mathrm{ADF}$ & 21.8 & 21.9 \\
\hline $\mathrm{NE}_{\mathrm{L}},{ }^{6} \mathrm{Mcal} / \mathrm{kg}$ & 1.62 & 1.62 \\
\hline
\end{tabular}

${ }^{1}$ Treatments: $\mathrm{NSB}=$ diet containing no sodium bicarbonate; $\mathrm{CTL}=$ diet with $0.75 \%$ sodium bicarbonate.

${ }^{2}$ Megalac, Church \& Dwight Co. Inc., Princeton, NJ.

${ }^{3}$ Contained $0.1 \% \mathrm{Ca} ; 0.6 \% \mathrm{P} ; 0.3 \% \mathrm{Mg} ; 11.5 \% \mathrm{Na} ; 0.23 \% \mathrm{~S} ; 6.2 \mathrm{mg}$ of $\mathrm{Co} / \mathrm{kg} ; 1,170 \mathrm{mg}$ of $\mathrm{Cu} / \mathrm{kg}$; $80 \mathrm{mg}$ of I/kg; 3,100 mg of Mn/kg; $40 \mathrm{mg}$ of Se/kg; 5,000 mg of Zn/kg; 1,265,000 IU of vitamin A/kg; 142,000 $\mathrm{IU}$ of vitamin $\mathrm{D} / \mathrm{kg}$; and 3,800 IU of vitamin $\mathrm{E} / \mathrm{kg}$.

${ }^{4} 10,000 \mathrm{IU} / \mathrm{kg}$.

${ }^{5}$ Starch content estimated to be $22 \%$ on a DM basis based on the study by Doepel et al. (2009) in which a diet equivalent to CTL was fed.

${ }^{6}$ Calculated based on a DMI of $21 \mathrm{~kg} / \mathrm{d}$ (NRC, 2001).

the same schedule as described previously (Doepel et al., 2009). Ruminal fluid $\mathrm{pH}$ was determined immediately after collection (Acumet XL15 pH meter, Fisher Scientific, Ottawa, ON, Canada), and samples were processed and stored at $-20^{\circ} \mathrm{C}$ until determination of VFA, lactate, and $\mathrm{NH}_{3}-\mathrm{N}$ as outlined by Doepel et al. (2009).

Whole-tract nutrient digestibility was determined using a modified method described by Holden et al. (1994). In brief, chromic oxide was inserted into the rumen twice daily ( $10 \mathrm{~g}$ each time) from d 14 to 21 of each period, and feces samples were collected on 12 occasions from d 18 to 21, composited, and then processed as described previously (Doepel et al., 2009).

Milk composition was determined by infrared spectroscopy (Milk-O-Scan 605; Foss Electric, Hillerød, Denmark) at the Central Milk Testing Laboratory (Edmonton, AB, Canada). Each of the 4 samples/cow per period was individually analyzed and the final com- 
Table 2. Dry matter intake and milk production of cows fed diets containing $20 \%$ steam-rolled wheat with or without sodium bicarbonate $^{1}$

\begin{tabular}{|c|c|c|c|c|}
\hline \multirow{2}{*}{$\begin{array}{l}\text { Response } \\
\text { variable }\end{array}$} & \multicolumn{2}{|c|}{ Treatment $^{2}$} & \multirow[b]{2}{*}{ SEM } & \multirow[b]{2}{*}{$P$-value } \\
\hline & NSB & CTL & & \\
\hline DMI, $\mathrm{kg} / \mathrm{d}$ & 21.3 & 20.7 & 0.43 & 0.31 \\
\hline \multicolumn{5}{|l|}{ Yield, $\mathrm{kg} / \mathrm{d}$} \\
\hline Milk & 31.4 & 30.2 & 1.85 & 0.64 \\
\hline Milk fat & 1.18 & 1.13 & 0.07 & 0.68 \\
\hline Milk protein & 1.03 & 0.98 & 0.05 & 0.50 \\
\hline Milk lactose & 1.43 & 1.37 & 0.10 & 0.68 \\
\hline \multicolumn{5}{|c|}{ Milk composition, \% } \\
\hline Fat & 3.76 & 3.78 & 0.11 & 0.90 \\
\hline Protein & 3.31 & 3.30 & 0.07 & 0.86 \\
\hline Lactose & 4.53 & 4.52 & 0.06 & 0.96 \\
\hline
\end{tabular}

${ }^{1}$ Data are presented as LSM with pooled SEM, $\mathrm{n}=12$.

${ }^{2} \mathrm{NSB}=$ diet containing no sodium bicarbonate; $\mathrm{CTL}=\operatorname{diet}$ with $0.75 \%$ sodium bicarbonate on a DM basis.

position calculated based on milk yield for each time. Milk component yield was calculated based on the final composition and the milk yield for the last $7 \mathrm{~d}$ of each period. Feed ingredients and feces were analyzed as described previously (Doepel et al., 2009).

\section{Statistics}

Milk yield was reduced to weekly means before statistical analysis. Production and digestibility data were analyzed using the MIXED procedure of SAS (SAS Institute, 1999), with treatment and period as the main effects and cow within period as the random effect. Rumen fermentation data were analyzed with time as the repeated measure using a model that included cow, period, treatment, time, and the treatment $\times$ time interaction. Treatment differences were considered significant when $P \leq 0.05$ and as a trend when $0.05<P \leq$ 0.10 . All data are reported as least squares means with pooled standard error of the means.

\section{RESULTS AND DISCUSSION}

\section{Lactation Performance}

Removal of $0.75 \%$ sodium bicarbonate from the diet had no effect on DMI, which averaged $21 \mathrm{~kg} / \mathrm{d}$ (Table 2 ). The lack of a DMI response to feeding buffers has been demonstrated previously (Kennelly et al., 1999; Khorasani and Kennelly, 2001). Similar to DMI, milk and milk component yields and milk composition also were unaffected by treatment (Table 2). As observed in our previous study (Doepel et al., 2009), feeding 20\% wheat with or without buffers did not result in milk fat depression. This may be related to the adequacy of dietary fiber in the present experiment (Table 1)
Table 3. Rumen fermentation characteristics of cows fed diets containing $20 \%$ steam-rolled wheat with or without sodium bicarbonate

\begin{tabular}{lcccc}
\hline & \multicolumn{2}{c}{ Treatment $^{2}$} & & \\
\cline { 2 - 3 } $\begin{array}{l}\text { Response } \\
\text { variable }\end{array}$ & $\mathrm{NSB}$ & $\mathrm{CTL}$ & SEM & $P$-value \\
\hline $\mathrm{pH}$ & 6.25 & 6.23 & 0.03 & 0.63 \\
$\mathrm{NH}_{3}$-N, mg/dL & 12.86 & 11.75 & 0.88 & 0.42 \\
Lactic acid, mM & 3.35 & 3.91 & 0.27 & 0.20 \\
Total VFA, mM & 109.9 & 116.4 & 1.76 & 0.06 \\
VFA, mol/100 mol & & & & \\
Acetate & 65.0 & 64.5 & 0.16 & 0.14 \\
Propionate & 19.8 & 20.2 & 0.26 & 0.41 \\
Butyrate & 10.4 & 10.5 & 0.10 & 0.63 \\
Isobutyrate & 0.93 & 0.95 & 0.02 & 0.46 \\
Valerate & 1.50 & 1.49 & 0.02 & 0.75 \\
Isovalerate & 1.76 & 1.73 & 0.06 & 0.78 \\
Caproate & 0.60 & 0.60 & 0.01 & 0.88 \\
A:P ratio & 3.29 & 3.24 & 0.07 & 0.63 \\
\hline
\end{tabular}

${ }^{1}$ Data are presented as LSM with pooled SEM, $\mathrm{n}=6$.

${ }^{2} \mathrm{NSB}=$ diet containing no sodium bicarbonate; CTL $=$ diet with $0.75 \%$ sodium bicarbonate on a DM basis.

${ }^{3}$ Acetate:propionate ratio.

as discussed by Krause and Oetzel (2006) and also to uncompromised fiber degradation associated with adequate ruminal $\mathrm{pH}$ (Tables 3 and 4 ) as reported by Kennelly et al. (1999). The lack of response in milk and milk component yields between treatments is likely related to the similarity in DMI and rumen fermentation variables (Seymour et al., 2005).

\section{Ruminal Fermentation}

The removal of sodium bicarbonate from the diet did not affect mean ruminal $\mathrm{pH}$ (Table 3 ) or the diurnal $\mathrm{pH}$ pattern (Figure 1). After feeding, ruminal $\mathrm{pH}$ decreased in all cows, but $\mathrm{pH}$ remained in the normal physiological range $(>5.8)$. In fact, at no point (Figure 1) did $\mathrm{pH}$ fall to a level $(\mathrm{pH}<5.0)$ that would allow lactateproducing bacteria to proliferate excessively (Owens et al., 1998; Stone, 2004). Rapid degradation of wheat starch may not result in acidosis as long as the diet con-

Table 4. Whole-tract apparent digestibility of nutrients of cows fed diets containing $20 \%$ steam-rolled wheat with or without sodium bicarbonate $^{1}$

\begin{tabular}{lcccc}
\hline & \multicolumn{2}{c}{ Treatment $^{2}$} & & \\
\cline { 2 - 3 } $\begin{array}{l}\text { Digestibility, } \\
\text { N }\end{array}$ & NSB & CTL & SEM & $P$-value \\
\hline DM & 75.1 & 75.5 & 1.5 & 0.87 \\
CP & 76.0 & 77.1 & 1.5 & 0.62 \\
ADF & 67.1 & 67.3 & 1.7 & 0.94 \\
NDF & 63.2 & 64.0 & 1.9 & 0.76 \\
\hline
\end{tabular}

${ }^{1}$ Data are presented as least squares means with pooled SEM, $\mathrm{n}=6$. ${ }^{2} \mathrm{NSB}=$ diet not containing sodium bicarbonate; CTL $=$ diet with $0.75 \%$ sodium bicarbonate on a DM basis. 


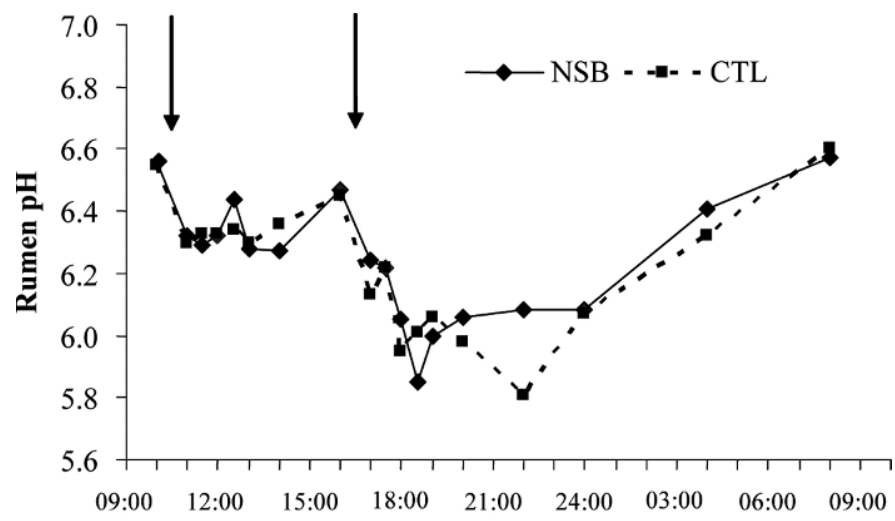

Time of day

Figure 1. Diurnal patterns of rumen $\mathrm{pH}$ as influenced by dietary treatment: without sodium bicarbonate (NSB) or with $0.75 \%$ sodium bicarbonate (CTL). Rumen $\mathrm{pH}$ was determined on d 20 and 21 of each period $(\mathrm{n}=6)$. Arrows indicate the time of feeding. $P$-value for treatment $=0.63 ;$ pooled $\mathrm{SEM}=0.03$.

tains sufficient effective NDF (Stercova et al., 2005), which stimulates mastication and saliva production. In the current experiment, inclusion of $20 \%$ steam-rolled wheat in the diet did not lead to a detrimental reduction in $\mathrm{pH}$, which may have diminished the likelihood of a sodium bicarbonate effect.

The average rumen concentration and diurnal pattern of ruminal $\mathrm{NH}_{3}-\mathrm{N}$ were unaffected by treatment $(P>0.10$; Table 3; Figure 2). This is in agreement with the study of Kennelly et al. (1999) in which rumen ammonia concentrations were not elevated by the addition of buffers to a diet containing $50 \%$ concentrate. However, in that study, an increase in rumen ammonia was seen in cows fed $75 \%$ concentrate in the diet indicating that the response of rumen ammonia to buffers may be dependent on diet composition and the level of fiber and nonstructural carbohydrates. There does not appear to be a consistent effect of sodium bicarbonate on rumen ammonia concentrations. Kilmer et al. (1981) reported that sodium bicarbonate supplementation resulted in increased ruminal ammonia concentrations, whereas Mees et al. (1985) reported that it decreased ammonia concentrations and increased bacterial $\mathrm{N}$ flow and efficiency of bacterial protein synthesis through depressing starch degradability and ruminal particulate dilution rate.

Regarding ruminal lactate, treatment did not affect the overall mean concentration $(P=0.20$, Table 3$)$; however, a treatment $\times$ time interaction $(P=0.03)$ was observed that was due primarily to a decrease in lactate from 1400 to $1600 \mathrm{~h}$ in the NSB cows and an increase during this same time frame for the CTL cows (Figure 3). With both treatments, total VFA concentration was lower than that needed $(130 \mathrm{~m} M)$ to trigger lactate formation (Russell, 1998). Thus, it is not surprising that lactate concentrations were similar between the 2 treatments. Kennelly et al. (1999), Khorasani and Kennelly (2001), and Marden et al. (2008) also observed no change in rumen lactate concentration with the addition of sodium bicarbonate to the diet. Total VFA concentrations for cows fed CTL tended to be higher than that for cows fed NSB (116 vs. $110 \mathrm{~m} M, P=0.06$; Table 3), which is similar to the increase observed by Khorasani and Kennelly (2001). However, none of the individual VFA concentrations or the ratio of acetate to propionate differed between the dietary treatments. These results are similar to those reported by $\mathrm{Xu}$ et al. (1994), who conducted 3 experiments with 2 types of buffers (Alkaten and Rumen 8) and found no consistent response in terms of VFA molar proportions. In contrast with the present study, Khorasani and Kennelly (2001) reported that $1.2 \%$ sodium bicarbonate in the diet altered rumen VFA pattern. In that study, buffer supplementation resulted in a higher rumen acetate concentration, but did not affect the propionate concentration. In a recent study conducted by Marden et al. (2008), cows fed $150 \mathrm{~g}$ of sodium bicarbonate/d had $11.7 \%$ greater total VFA compared with the control cows, with an increase in acetate proportion but no change in propionate and butyrate proportions. The lack of a VFA response to buffer feeding may be related to the forage:concentrate ratio and the type of forage in the diet. In the current experiment, alfalfa constituted one-third of the forage component of the diet. In

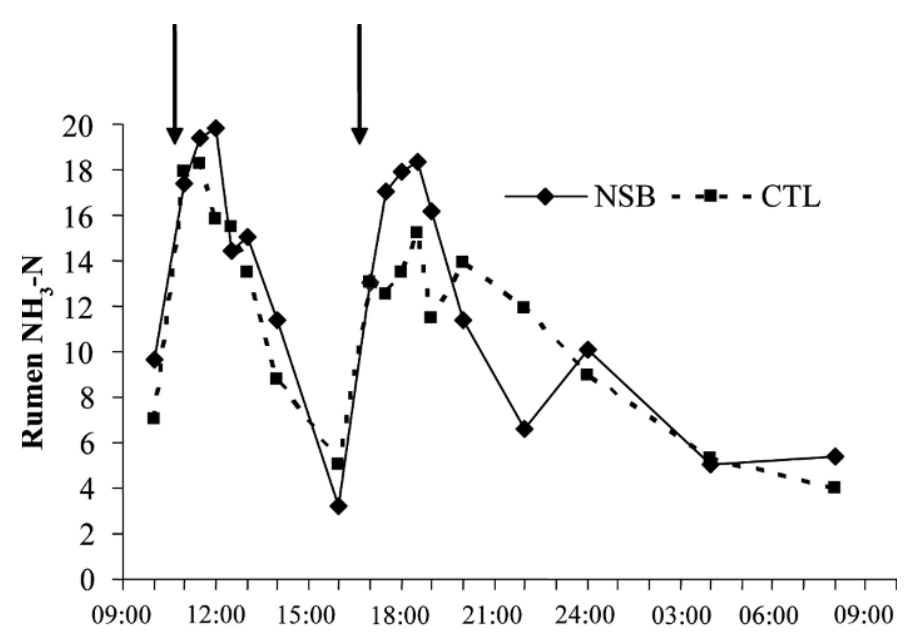

Time of day

Figure 2. Diurnal patterns of rumen $\mathrm{NH}_{3}-\mathrm{N}(\mathrm{mg} / \mathrm{dL})$ as influenced by dietary treatment: without sodium bicarbonate (NSB) or with $0.75 \%$ sodium bicarbonate (CTL). Rumen $\mathrm{NH}_{3}-\mathrm{N}$ was determined on d 20 and 21 of each period $(n=6)$. Arrows indicate the time of feeding. $P$-value for treatment $=0.42$; pooled $\mathrm{SEM}=0.88$. 


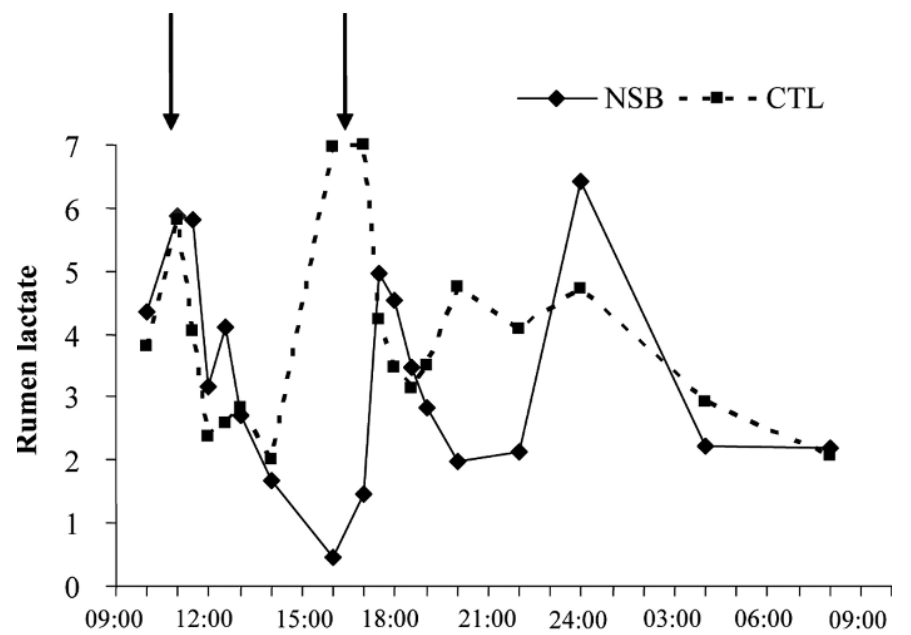

Time of day

Figure 3. Diurnal patterns of rumen lactate $(\mathrm{m} M)$ as influenced by dietary treatment: without sodium bicarbonate (NSB) or with $0.75 \%$ sodium bicarbonate (CTL). Rumen lactate was determined on d 20 and 21 of each period $(\mathrm{n}=6)$. Arrows indicate the time of feeding. $P$-value for treatment $=0.20 ; P$-value for treatment $\times$ time $=0.03$; pooled SEM $=0.27$.

general, forages rich in protein (alfalfa silage $>$ barley silage $>$ corn silage) have greater buffering capacity (Crawford et al., 1983) such that the efficacy of sodium bicarbonate supplementation diminishes when diets contain alfalfa forage (DePeters et al., 1984).

\section{Nutrient Digestibility}

Whole-tract apparent nutrient digestibility is shown in Table 4. Treatment did not affect the digestibility of DM, CP, ADF, and NDF, which averaged 75.3, 76.6, 67.2 , and $63.6 \%$, respectively. The lack of treatment differences with regard to fiber digestion is not surprising considering that rumen $\mathrm{pH}$ did not differ between NSB and CTL cows. Moderate depression in $\mathrm{pH}$ to approximately 6.0 results in a small decrease in fiber digestion, but numbers of fibrolytic organisms are usually not affected. Further decreases to 5.5 or 5.0 result in depressed growth rates and decreased fibrolytic microbes (Therion et al., 1982; Hoover, 1986), but not amylolytic species (Terry et al., 1969; Therion et al., 1982), and fiber digestion may be completely inhibited. The lack of difference between treatments in whole-tract apparent digestibility (Table 4) and production variables (Table 1 ) is in agreement with the absence of subacute acidosis as measured by rumen $\mathrm{pH}$ (Figure 1) or changes in VFA patterns (Table 3) and concentrations of other rumen metabolites $\left(\mathrm{NH}_{3}-\mathrm{N}\right.$ and lactate; Figures 2 and $3)$. This suggests that rumen microbes have the ability to adapt to a moderate amount of wheat grain in the diet; however, adaptation may be exceeded by the rate of ruminal fermentation when wheat is offered at high levels (50\%; Krajcarski-Hunt et al., 2002) due to lowered $\mathrm{pH}$ and its detrimental effect on fiber degradation (Nordlund et al., 1995). Our data are in agreement with those of Mees et al. (1985) who reported no changes in $\mathrm{OM}$ and NDF digestibility in response to sodium bicarbonate supplementation, which was explained by the increased passage rate of particulate matter. Passage rate was not measured in the current study. Similarly, other studies have shown no effects of sodium bicarbonate on OM and NDF digestibility when accompanied by either an altered (Rogers et al., 1985; Kennelly et al., 1999; Marden et al., 2008) or unaltered (Kalscheur et al., 1997) rumen VFA pattern.

\section{CONCLUSIONS}

Exclusion of sodium bicarbonate from a diet containing 20\% steam-rolled wheat did not compromise feed intake, milk yield, or milk composition. Similarly, rumen fluid $\mathrm{pH}$, rumen $\mathrm{NH}_{3}-\mathrm{N}$ and lactate concentrations, and VFA pattern were unaltered by the removal of sodium bicarbonate from the diet. With the diet used in this study, it can be concluded that wheat can be safely fed to lactating dairy cows without the use of rumen buffers in the form of sodium bicarbonate. Future studies should concentrate on determining the maximum amount of wheat that can be fed, with and without buffer, without compromising production and causing subacute ruminal acidosis in dairy cows.

\section{REFERENCES}

CCAC. 1993. Guide to the Care and Use of Experimental Animals. Vol. 1. 2nd ed. Canadian Council on Animal Care, Ottawa, ON, Canada.

Crawford, R. J. Jr., B. J. Shriver, G. A. Varga, and W. H. Hoover. 1983. Buffer requirements for maintenance of $\mathrm{pH}$ during fermentation of individual feeds in continuous cultures. J. Dairy Sci. 66:1881-1890.

DePeters, E. J., A. H. Fredeen, D. L. Bath, and N. E. Smith. 1984. Effect of sodium bicarbonate addition to alfalfa hay-based diets on digestibility of dietary fractions and rumen characteristics. J. Dairy Sci. 67:2344-2355.

Doepel, L., A. Cox, and A. Hayirli. 2009. Effects of increasing amounts of dietary wheat on performance and ruminal fermentation of Holstein cows. J. Dairy Sci. 92:3825-3832.

Garrett, E. F., M. N. Pereira, K. V. Nordlund, L. E. Armentano, W. J. Goodger, and G. R. Oetzel. 1999. Diagnostic methods for the detection of subacute ruminal acidosis in dairy cows. J. Dairy Sci. 82:1170-1178.

Holden, L. A., L. D. Muller, G. A. Varga, and P. J. Hillard. 1994. Ruminal digestion and duodenal nutrient flows in dairy cows consuming grass as pasture, hay, or silage. J. Dairy Sci. 77:3034-3042.

Hoover, W. H. 1986. Chemical factors involved in ruminal fiber digestion. J. Dairy Sci. 69:2755-2766.

Kalscheur, K. F., B. B. Teter, L. S. Piperova, and R. A. Erdman. 1997. Effect of dietary forage concentration and buffer addition on duodenal flow of trans-C18:1 fatty acids and milk fat production in dairy cows. J. Dairy Sci. 80:2104-2114. 
Kennelly, J. J., B. Robinson, and G. R. Khorasani. 1999. Influence of carbohydrate source and buffer on rumen fermentation characteristics, milk yield, and composition in early-lactation Holstein cows. J. Dairy Sci. 82:2486-2496.

Khorasani, G. R., and J. J. Kennelly. 2001. Influence of carbohydrate source and buffer on rumen fermentation characteristics, milk yield, and milk composition in late-lactation Holstein cows. J. Dairy Sci. 84:1707-1716.

Kilmer, L. H., L. D. Muller, and T. J. Snyder. 1981. Addition of sodium bicarbonate to rations of postpartum dairy cows: Physiological and metabolic effects. J. Dairy Sci. 64:2357-2369.

Krajcarski-Hunt, H., J. C. Plaizier, J. P. Walton, R. Spratt, and B. W. McBride. 2002. Effect of subacute ruminal acidosis on in situ fiber digestion in lactating dairy cows. J. Dairy Sci. 85:570-573.

Krause, K. M., and G. R. Oetzel. 2006. Understanding and preventing subacute ruminal acidosis in dairy herds: A review. Anim. Feed Sci. Technol. 126:215-236.

Le Ruyet, P., and W. B. Tucker. 1992. Ruminal buffers: Temporal effects on buffering capacity and $\mathrm{pH}$ of ruminal fluid from cows fed a high concentrate diet. J. Dairy Sci. 75:1069-1077.

Marden, J. P., C. Julien, V. Monteils, E. Auclair, R. Moncoulon, and C. Bayourthe. 2008. How does live yeast differ from sodium bicarbonate to stabilize ruminal $\mathrm{pH}$ in high-yielding dairy cows? J. Dairy Sci. 91:3528-3535.

Mees, D. C., N. R. Merchen, and C. J. Mitchel. 1985. Effects of sodium bicarbonate on nitrogen balance, bacterial protein synthesis and sites of nutrient digestion in sheep. J. Anim. Sci. 61:985-994.

Nordlund, K. V., E. F. Garrett, and G. R. Oetzel. 1995. Herd-based rumenocentesis: A clinical approach to the diagnosis of subacute rumen acidosis. Compend. Cont. Educ. Pract. 17:S48-S56.

NRC. 2001. Nutritional Requirements of Dairy Cattle. 7th rev. ed. Natl. Acad. Sci., Washington, DC.

Owens, F. N., D. S. Secrist, W. J. Hill, and D. R. Gill. 1998. Acidosis in cattle: A review. J. Anim. Sci. 76:275-286.
Rogers, J. A., L. D. Muller, C. L. Davis, W. Chalupa, D.S. Kronfeld, L. F. Karcher, and K. R. Cummings. 1985. Response of dairy cows to sodium bicarbonate and limestone in early lactation. J. Dairy Sci. 68:646-660.

Russell, J. B. 1998. The importance of $\mathrm{pH}$ the regulation of ruminal acetate to propionate ratio and methane production in vitro. J. Dairy Sci. 81:3222-3230.

Russell, J. B., and J. M. Chow. 1993. Another theory for the action of ruminal buffer salts: Decreased starch fermentation and propionate production. J. Dairy Sci. 76:826-830.

SAS Institute. 1999. SAS User's Guide. Version 8. SAS Inst., Inc., Cary, NC.

Seymour, W. M., D. R. Campbell, and Z. B. Johnson. 2005. Relationship between rumen volatile fatty acid concentrations and milk production in dairy cows: A literature study. Anim. Feed Sci. Technol. 119:155-169.

Stercova, E., V. Pazout, E. Strakova, and P. Suchy. 2005. Effect of intensive fattening of bulls based on a high-grain diet on growth intensity and biochemical and acid-base parameters of blood. Czech J. Anim. Sci. 50:355-361.

Stone, W. C. 2004. Nutritional approaches to minimize subacute ruminal acidosis and laminitis in dairy cattle. J. Dairy Sci. 87 (E. Suppl.):E13-E26.

Terry, R. A., J. M. A. Tilley, and G. E. Outen. 1969. Effect of pH on cellulose digestion under in vitro conditions. J. Sci. Food Agric. $20: 317-320$.

Therion, J. J., A. Kistner, and J. H. Kornelius. 1982. Effect of pH on growth rates of rumen amylolytic and lactilytic bacteria. Appl. Environ. Microbiol. 44:428-434.

Xu, S., J. H. Harrison, L. R. E. Riley, and K. A. Loney. 1994. Effect of buffer addition to high grain total mixed rations on rumen $\mathrm{pH}$, feed intake, milk production, and milk composition. J. Dairy Sci. $77: 782-788$. 